$\frac{\mathrm{DE}}{\mathrm{G}} \stackrel{\begin{array}{l}\text { DE GRUYTER } \\ \text { OPEN }\end{array}}{\text { EOI 10.1515/ethemes-2015-0029 }}$

\title{
THE DIFFERENCES IN THE IMPORTANCE OF CERTAIN ASPECTS OF BUSINESS SUCCESS FOR FEMALE ENTREPRENEURS OF DIFFERENT AGE AND EDUCATION
}

\author{
Danijela Stošić \\ University of Niš, Faculty of Economics, Serbia \\ $\triangle$ danijela.stosic@eknfak.ni.ac.rs
}

\section{UDC}

$334.722-055.2$

Original

scientific paper

Received:

29.11.2015

Accepted:

17.12 .2015

\begin{abstract}
The aim of this paper is to examine the importance of different aspects of business success for different age and educational groups of female entrepreneurs in the Republic of Serbia. An empirical study was conducted on a sample of 40 female entrepreneurs from several urban areas in the Republic of Serbia. The data are analysed by conducting the Principal Component Analysis (PCA) and one-way Multivariate Analysis of Variances (MANOVA). Results show that all different aspects of business success that were examined can be grouped around two main dimensions - qualitative and quantitative one. Although certain differences in the importance of these dimensions between female entrepreneurs of different age and education were found, they were not statistically important. However, this research can be seen as a pilot study, so further research, which would possibly presuppose a realization of a larger sample, can be carried out starting from the defined conceptual and methodological framework.
\end{abstract}

Keywords: female entrepreneurship, business success, education, age

\section{Introduction}

One of the most pronounced aspect of the entrepreneurial activity is the increment of the volume and importance of female entrepreneurial activity. Although gaining in its intensity, female entrepreneurial activity is still lagging behind the entrepreneurial activity of man - both in its volume and in business performances (Coleman and Robb, 2009; Kamberidou, 2013; Klapper and Parker, 2010; Xavier et al., 2012). Therefore, it is stated that female entrepreneurial potential is vital, but the underutilised source of economic 
growth and development (Vossenberg, 2013; Zwan et al., 2012). Reasons for this gender gap in the entrepreneurial performances are well studied and can be sorted into different groups (more in: Stošić, 2015). There are empirical results suggesting that the correlation may be found between entrepreneurial motives, the way in which they assess certain aspects of business success and their business performances (Buttner and Moore, 1997; Carter and Bennett, 2006; Cliff, 1998). Moreover, some authors find evidence that female entrepreneurs prioritise qualitative aspects of business success which is the reason why they achieve worse business performances (Carter and Bennett, 2006). In that sense, it may be important to analyse different aspects of business success that female entrepreneurs evaluate as important, and to examine whether there are differences between different groups of female entrepreneurs regarding this issue.

Entrepreneurial activity of women in the Republic of Serbia is a part of the overall entrepreneurial activity that should be encouraged in order to achieve the strategic objectives of improving competitiveness and innovation in the small business sector (Government of the Republic of Serbia, 2015). Success in defining and implementing various support measures requires proper theoretical foundations in a form of the results of empirical research of the entrepreneurial activity of women. Although recognized as significant, gender aspect of entrepreneurship in the Republic of Serbia is insufficiently researched area. With the aim to contribute to the analysis of the characteristics of women's entrepreneurial activity in the Republic of Serbia, the paper presents the results of research on this phenomenon, focusing on the question of perception of business success by female entrepreneurs. The survey was conducted on a sample of 40 female entrepreneurs from several urban areas in the Republic of Serbia. Principal components analysis (PCA) was performed in order to reduce the number of different aspects of business success that female entrepreneurs evaluate. After that, the one-way multivariate analysis of variance was performed in order to examine whether there were differences in the valuation of business success between different age and educational groups of female entrepreneurs.

As for the remaining part of the paper, after the literature review on the subject and the definition of the hypotheses, the methodological points of the study are explained. Results are presented in the fourth chapter of the paper after which they are discussed. Certain conclusions are outlined in the final part of the paper.

\section{Literature Review}

It is suggested that female entrepreneurs are dominantly motivated by qualitative motives to start their own businesses (motives like: independence, flexibility of working time and alike), that they are then less oriented towards 
quantitative business goals, and that this may be one of the reasons why they achieve lower business performances (Carter and Bennet, 2006; Knorr et al., 2011). Therefore, the gender gap in the entrepreneurial business performances can be viewed through the prism of the aspects of the business success that are emphasized by female and male entrepreneurs. Namely, in accordance with their primary motive, female entrepreneurs tend to assess their business dominantly from the internal point of view (for example: through the achievement of personal development), and to a lesser extent they use external indicators of success such as profitability and growth (Buttner and Moore, 1997; Rosa et al., 1994). Valuating the business success in that way, female entrepreneurs can direct the most of their effort on achieving the qualitative aspects of the business success that then can explain the gender gap in the quantitatively measured business performances in favour of male entrepreneurs. In that sense, it is suggested that, being more qualitative oriented and having a relational perspective while managing their businesses, most of the female entrepreneurs feel a responsibility for customers and use customer loyalty as a measure of business success (Morris et al., 2006; Tan, 2008).

Differently shaped processes of socialization of women and men are translated into the business sphere where men assess the business success through business growth, while women use less objective criteria. Therefore, the differences in the importance of different aspects of the business success can determine the growth of the businesses owned and managed by women. If a qualitative aspect of the business success is the primary dimension of the business success that female entrepreneurs valuate, that can affect the difference in the growth orientation of female and male entrepreneurs (Robichaud et al., 2007). If female entrepreneurs initially do not define quantitative growth as their business goal, they will not seek to realize the growth of their companies. In that sense, it is suggested that the orientation toward growth is higher for male entrepreneurs (Orser and Hogarth-Scott, 2002). Compared to female entrepreneurs for whom the quantitative growth of their businesses is of secondary importance, business growth is significant goal which is more likely to be achieved by businesses owned male entrepreneurs (Orser and HogarthScott, 2002; Verheul and Thurik, 2001). In most cases, "women-owned businesses start out as small and they stay small" (Alsos et al., 2006, p. 681; Bowen and Hisrich, 1986, p. 402). The lower limit of the target size that women define for their businesses is a result of their greater risk aversion, but also the result of the fact that the qualitative aspect of the business success is more significant for female entrepreneurs (Watson, 2002).

There is no doubt that business success is a complex phenomenon with both - quantitative and qualitative aspects. Therefore, business success measured in financial terms is just one of the goals in the broad spectrum of female entrepreneurs' business goals (Bird and Sapp, 2004; Carter et al., 2003; 
Chaganti and Parasuraman, 1996). Although female entrepreneurs may not be primarily motivated by financial incentives, it does not mean that these are not important business goals for them (Bird and Sap, 2004). It may be that female entrepreneurs have more diversified spectrum of business goals with a dominance of the nonfinancial ones (Bird and Sap, 2004; Jome et al., 2006). Moreover, regarding that issue, female entrepreneurs may not be a homogeneous group. Analysing successful midlife professional women, Gordon and Whelan (1998) state that there is a significant cognitive shift in terms of defining business success, a shift that is related to the years of the respondent. Midlife professional women's definition of success has been changed over time in a sense that they now use less traditional (masculine) terms and develop more individual definitions of success. Exploring the female entrepreneurs' motivation to start their own businesses, Budig (2006) argues that there is a difference between female entrepreneurs engaged in the nonprofessional and those working in the professional occupations. Female entrepreneurs from the second group are older, more educated, engaged in male dominated occupations and they have more interest in the financial aspect of the business success.

Within presented theoretical framework, it is hypothesised that:

H1: Different aspects of the business success assessed by female entrepreneurs can be grouped around two main dimensions: qualitative and quantitative one.

H2: There is a difference in the importance of different dimensions of business success between female entrepreneurs of different age and education.

\section{Methodology}

\subsection{Variables, Sample and Data Collection}

Research was conducted on the sample of 40 female owners of small and medium sized enterprises and women registered as entrepreneurs according to the Serbian Law (National Assembly of the Republic of Serbia, 2011, arts. 2, 83). Research period was from July to October 2014. The sample is generated from several databases of female entrepreneurs. ${ }^{1}$ Geographically, sample units were from urban areas in the Republic of Serbia. This sample characteristic is in line with the results presented by Babović (2012, p. 57) which suggest that the most of the female entrepreneurs in the Republic of Serbia are located in the urban areas (four out of five female entrepreneurs in the Republic of Serbia live

\footnotetext{
${ }^{1}$ Female Entrepreneurs Databases of: Chamber of Commerce and Industry of Serbia; First Women's Club; Institute for Gender Equality of Province of Vojvodina; Association of Business Women Nadežda Petrović, Čačak; Association of Business Women, Subotica; Female Entrepreneurship Network Fenomena, Kraljevo; Centre for female entrepreneurship Teodora, Niš; several commercial banks' databases (banks' representatives explicitly refused the possibility for bank's name to be mentioned in the paper).
} 
in urban areas). The questionnaire was distributed by e-mail or personally to the entrepreneurs. Unfortunately, the response rate could not be calculated because the size of the initial sample was not known. Namely, a number of the female entrepreneurs from the available databases were contacted by the representatives of the entrepreneurial associations or banks. Therefore, the total number of the female entrepreneurs that have received the questionnaire was unknown to the researcher.

Business success as a depended variable was assessed on a continuum of eight different aspects of business success (as stated by the respondents) - profit growth (PfGr), employment growth (EpmlGr), personal wealth (PrsnlWlth), personal goals (PrsnlGoals), customer satisfaction and loyalty (SatLoyCust), employee satisfaction and development (SatDevEmpl), relationships with employees and customers (RelEmplCust), family-work balance (FamWorkBal). Five-point Likert scale was used to measure the importance of different aspects of business success ( 1 - completely insignificant; 2 - insignificant; 3 - neutral; 4 - important, 5 - particularly significant).

Education and age of the respondents were defined as independent variables. The education was measured by the educational level of the respondents - EduLev (without primary education; primary education; high school; college; bachelor; master; $\mathrm{PhD}$ ), and by the field of their education EduField (Services; General programmes; Education; Social sciences, business and law; Agriculture and veterinary; Humanities and arts; Science; Health and welfare; Engineering, manufacturing and construction). The level of education or educational achievement (EduLev) was determined by the highest level of school completed in the officially recognized education system. The International Standard Classification of Education was used to define the field of education (EduField) as a qualitative and subject-specific characteristic of the education (UNESCO Institute for Statistics, 2012). ${ }^{2}$ Four age groups were defined: up to 25 years old; $26-45 ; 46-65$ and 66 and more years old.

Demographic characteristics of the sample revealed that the most of the female entrepreneurs in the sample were 26-45 age old, that the most of them had completed high school and that they were mostly educated in the field of Social sciences, business and law (Table 1). As all of them had not completely answered the questionnaire, the demographic characteristics of their business could not be determined.

\footnotetext{
${ }^{2}$ International Standard Classification of Education (ISCED) was also used by the Statistical Office of the Republic of Serbia in the Labour Force Survey and the Survey of the Adults' Education. The classification originated from 1997 was used in these surveys (ISCED 1997). However, there is no difference between ISCED 1997 and ISCED 2011 in terms of the identified fields of education.
} 
Table 1 Age and Education of the Sample Units

\begin{tabular}{lr}
\hline & Frequency (Percent) \\
\cline { 2 - 2 } Age & \\
$26-45$ & $4(10.00)$ \\
$46-65$ & $24(60.00)$ \\
66 and more & $12(30.00)$ \\
\hline Total & $0(0.00)$ \\
\hline Education - Last completed Level & $40(100.00)$ \\
\hline Without Primary Education & \\
Primary Education & $0(0.00)$ \\
High School & $0(0.00)$ \\
College & $18(45.00)$ \\
Bachelor & $5(12.50)$ \\
Master & $12(30.00)$ \\
PhD & $4(10.00)$ \\
\hline Total & $1(2.5)$ \\
\hline Education - Field of the Last Completed Level & $40(100.00)$ \\
\hline Services & \\
General programmes & $8(20.00)$ \\
Education & $5(12.50)$ \\
Social sciences, business and law & $8(20.00)$ \\
Agriculture and veterinary & $9(22.50)$ \\
Humanities and arts & $2(5.00)$ \\
Science & $1(2.50)$ \\
Health and welfare & $3(7.50)$ \\
Engineering, manufacturing and construction & $3(7.50)$ \\
Total & $1(20.50)$ \\
\hline & $40(100.00)$ \\
\hline
\end{tabular}

\subsection{Statistical Methods}

Factor reduction was conducted in order to simplify the analysis and to group different aspects of business success. Namely, for the reduction of the business success measures, the PCA (Principal Component Analysis) with Varimax rotation was carried out. The existence of the linear relations between variables was checked by the scatterplot. In order to test the existence of the outliers, it was determined that the outliers would be identified as those component scores that are more than three standard deviation away from the mean. For a variable to be included in the analysis, it was supposed to satisfy the critical level of correlation defined as $|r| \geq 0.3$. The minimum requirement for sampling adequacy was set at 0.6 for the overall and for the KMO (Kaiser-Meyer-Olkin) measure for individual variables. Bartlett's test of sphericity $(p<0.05)$ was used to assess the suitability of the data for the PC analysis. The number of components to be retained was decided on the basis of the eigenvalue-one criterion (Kaiser criterion). The Cronbach's alpha measure of the internal consistency was determined to measure how much the items on the scale were measuring the 
same construct (critical value: Cronbach's $\alpha \geq 0.60$ ). After doing that, a component-based score was calculated, for each sample unit - as an average value of the scores on all the variables that loaded strongly to the particular component. That component-based score was then used in the subsequent analysis. There was no need for reverse coding, as each item contributed to the scale in the same direction.

One-way multivariate analysis of variance (MANOVA) is used to test the mean differences of extracted components of the business success between different age and educational groups of participants. The assumptions concerning univariate and multivariate outliers were checked by visual inspection of the boxplot and by value of Mahalanobis distance (critical value 13.82), respectively. As a method of detecting multicollinearity between dependent variables the Pearson correlation coefficient was used. The existence of linear relationship between dependent variables for each group of independent variable was assessed by the scatterplot. The homogeneity of variance-covariance matrices was assessed by Box's test of equality of covariance matrices. Wilks' Lambda $(\Lambda)$ multivariate statistics was used to test the statistical significance of the differences between groups. These analyses were conducted by using the SPSS (Statistical Package for Social Science, Ver. 22).

\section{Results}

Different aspects of business success, as assessed by the respondents, were classified in two groups by using PC analysis. ${ }^{3}$ Before conducting the PC analysis itself, it was determined that the assumptions for conducting the analysis were met. Namely, the variables were linearly related, and there were no outliers in the data. As it can be seen in Table 2, the presumption regarding the correlation coefficients was met (all variables had at least one $|r| \geq 0.3$ ).

Table 2 Correlation Matrix

\begin{tabular}{lcccccccc}
\hline & \multicolumn{6}{c}{ PfGr } & \multicolumn{6}{c}{ EmplGr PrsnlWlth PrsnlGoals SatLoyCust SatDevEmpl RelEmplCust FamWorkBal } \\
\cline { 2 - 9 } PfGr & 1.000 & .619 & .619 & .809 & .422 & .416 & .485 & .461 \\
EmplGr & .619 & 1.000 & .527 & .540 & .306 & .691 & .502 & .445 \\
PrsnlWlth & .619 & .527 & 1.000 & .631 & .389 & .379 & .266 & .456 \\
PrsnlGoals & .809 & .540 & .631 & 1.000 & .615 & .451 & .435 & .603 \\
SatLoyCust & .422 & .306 & .389 & .615 & 1.000 & .633 & .669 & .656 \\
SatDevEmpl & .416 & .691 & .379 & .451 & .633 & 1.000 & .796 & .563 \\
RelEmplCust & .485 & .502 & .266 & .435 & .669 & .796 & 1.000 & .575 \\
FamWorkBal & .461 & .445 & .456 & .603 & .656 & .563 & .575 & 1.00 \\
\hline
\end{tabular}

${ }^{3}$ The PCA results are also presented in the paper entitled Aspects of the Business Success Important to Female Entrepreneurs in Urban Areas of the Republic of Serbia - A Pilot Study (forthcoming). 
The overall KMO measure showed that the sample was adequate (Table 3 ). Moreover, data were factorizable as suggested by the Barltett's test of sphericity that was statistically significant $(\mathrm{p}=0.0001)$, and all the individual KMO measures were greater than 0.7 .

Table 3 KMO and Bartlett's Test

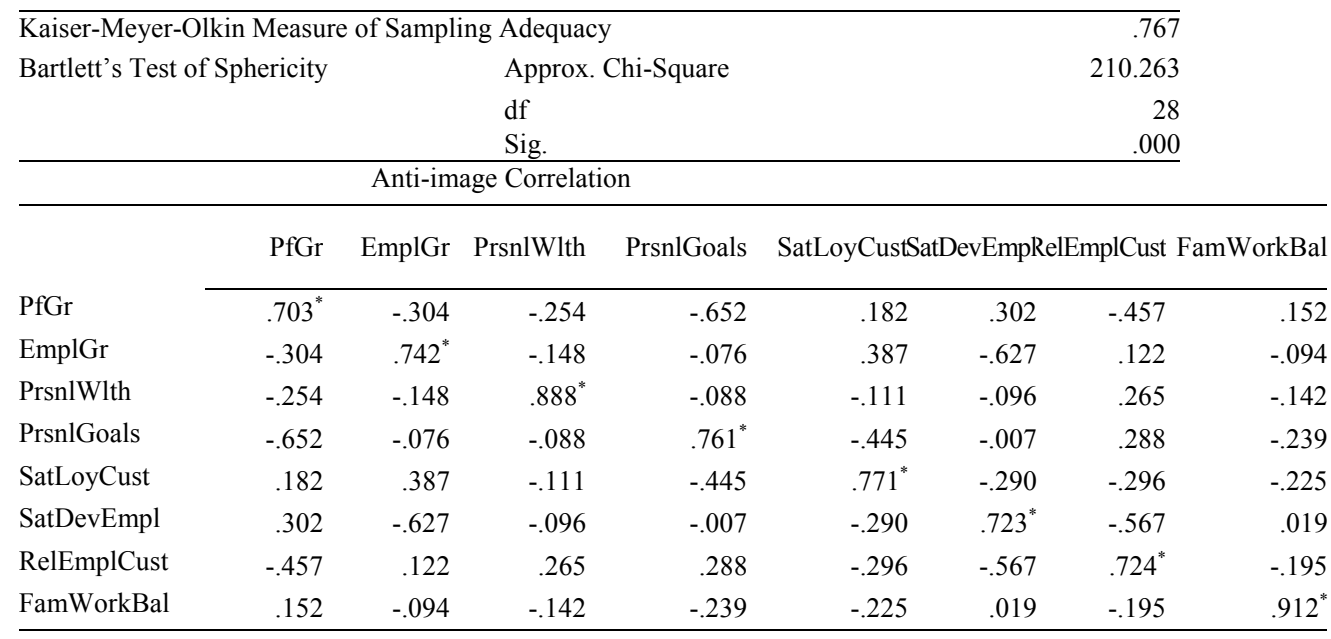

"Measures of Sampling Adequacy

As PC analysis showed, two components had eigenvalues greater than one (Table 4). These components explained $59.39 \%$ and $14.36 \%$ of the total variance, respectively, or cumulatively $-73.75 \%$ of the variance was explained.

Table 4 Total Variance Explained

\begin{tabular}{|c|c|c|c|c|c|c|c|c|c|}
\hline \multirow[b]{2}{*}{ Component } & \multicolumn{3}{|c|}{ Initial Eigenvalues } & \multicolumn{3}{|c|}{$\begin{array}{c}\text { Extraction Sums of Squared } \\
\text { Loadings }\end{array}$} & \multicolumn{3}{|c|}{$\begin{array}{l}\text { Rotation Sums of Squared } \\
\text { Loadings }\end{array}$} \\
\hline & Total & $\begin{array}{c}\% \text { of } \\
\text { Variance }\end{array}$ & $\begin{array}{c}\text { Cumulative } \\
\%\end{array}$ & Total & $\begin{array}{c}\% \text { of } \\
\text { Variance }\end{array}$ & $\begin{array}{c}\text { Cumulative } \\
\%\end{array}$ & Total & $\begin{array}{c}\% \text { of } \\
\text { Variance }\end{array}$ & $\begin{array}{c}\text { Cumulative } \\
\%\end{array}$ \\
\hline 1 & 4.751 & 59.389 & 59.389 & 4.751 & 59.389 & 59.389 & 3.030 & 37.869 & 37.869 \\
\hline 2 & 1.149 & 14.364 & 73.753 & 1.149 & 14.364 & 73.753 & 2.871 & 35.884 & 73.753 \\
\hline 3 & .780 & 9.748 & 83.501 & & & & & & \\
\hline 4 & .469 & 5.864 & 89.364 & & & & & & \\
\hline 5 & .371 & 4.639 & 94.003 & & & & & & \\
\hline 6 & .262 & 3.272 & 97.274 & & & & & & \\
\hline 7 & .125 & 1.564 & 98.839 & & & & & & \\
\hline 8 & .093 & 1.161 & 100.000 & & & & & & \\
\hline
\end{tabular}


Based on component loadings and their communalities (Table 5), it can be concluded that the business success aspects can be reduced on two components. Given the nature of the items loaded on these two dimensions, it can be concluded that the female entrepreneurs' perception of the business success has a qualitative and a quantitative dimension. Therefore, it can be stated that the first hypothesis can be accepted. Items like relationships with employees and customers, employee satisfaction and development, customer satisfaction and loyalty, family-work balance are loaded on the qualitative component, while variables referring to profit growth, personal wealth, personal goals and employment growth are related to the quantitative component.

Table 5 Rotated Structure Matrix for PCA with Varimax Rotation of a Two Component Questionnaire

\begin{tabular}{lrrr}
\hline \multirow{2}{*}{ Items } & \multicolumn{2}{c}{ Rotated Component Coefficients } & Communalities \\
\cline { 2 - 3 } & $\begin{array}{r}\text { Component } 1- \\
\text { Qualitative }\end{array}$ & $\begin{array}{r}\text { Component 2- } \\
\text { Quantitative }\end{array}$ & .836 \\
\hline RelEmplCust & $\underline{.897}$ & .179 & .812 \\
SatDevEmpl & $\underline{.863}$ & .258 & .700 \\
SatLoyCust & $\underline{.787}$ & .282 & .625 \\
FamWorkBal & $\underline{.672}$ & .417 & .806 \\
PfGr & .265 & $\underline{.858}$ & .730 \\
PrsnlWlth & .139 & $\underline{.843}$ & .806 \\
PrsnlGoals & .357 & $\underline{.824}$ & .585 \\
EmplGr & .438 & $\underline{.627}$ & \\
\hline
\end{tabular}

Note: Major loadings for each item are underlined

Extraction Method: Principal Component Analysis.

Rotation Method: Varimax with Kaiser Normalization. Rotation converged in 3 iterations.

One-way MANOVA was used to determine whether there was a difference in the mean values of the component scores for female entrepreneurs of different age and different level/field of education. As for the different age group analysis, there was one univariate outlier in the data referring the component scores as assessed by inspection of a boxplot (case number 34). This case was excluded from further analysis. There was no multicollinearity, as assessed by Pearson correlation coefficient $(\mathrm{r}=0.345, \mathrm{p}=0.031)$. According to Mahalanobis distance, there were no multivariate outliers in the data. Box's test of equality of covariance matrices $(p=0.753)$ suggested that there was a homogeneity of variance-covariances matrices. There were no participants older than 66 years in the sample. In each other age group there were more than two cases (up to 25 : 4 ; 26-45: 23; 46-65: 12). Table 6 displays descriptive statistics for each level of the independent variable. 
Table 6 Age - Descriptive Statistics

\begin{tabular}{lrrrrrr}
\hline & & & & \multicolumn{2}{c}{$95 \%$ Confidence Interval } \\
\cline { 5 - 7 } Dependent Variable & Age & Mean & $\begin{array}{c}\text { Std. } \\
\text { Error }\end{array}$ & $\begin{array}{c}\text { Lower } \\
\text { Bound }\end{array}$ & $\begin{array}{c}\text { Upper } \\
\text { Bound }\end{array}$ \\
\hline Component 1 - Qualitative & up to 25 & 4.813 & .247 & 4.311 & 5.314 \\
& $26-45$ & 4.482 & .103 & 4.273 & 4.691 \\
& $46-65$ & 4.333 & .143 & 4.044 & 4.623 \\
\hline Component 2 - Quantitative & up to 25 & 4.313 & .326 & 3.651 & 4.974 \\
& $26-45$ & 4.130 & .136 & 3.854 & 4.406 \\
& $46-65$ & 3.729 & .188 & 3.347 & 4.111 \\
\hline
\end{tabular}

The importance of both qualitative and quantitative dimensions of business success is decreasing with age, being most pronounced in the youngest group of the entrepreneurs. Nevertheless, there was no statistically significant difference between the age groups on the combined dependent variables (Table 7).

Table 7 Wilk's Lambda Multivariate Tests

\begin{tabular}{llcrrrrr}
\hline Effect & & Value & F & Hypothesis df & $\begin{array}{c}\text { Error } \\
\text { df }\end{array}$ & Sig. & \multicolumn{2}{c}{$\begin{array}{c}\text { Partial Eta } \\
\text { Squared }\end{array}$} \\
\cline { 3 - 8 } Age & Wilks' Lambda & .866 & 1.310 & 4.000 & 70.000 & .275 & .070 \\
EduLev & Wilks' Lambda & .847 & .952 & 6.000 & 66.000 & .465 & .080 \\
EduField & Wilks' Lambda & .635 & 1.274 & 12.000 & 60.000 & .257 & .203 \\
\hline
\end{tabular}

Regarding the analysis of different educational level groups, preliminary assumption checking revealed that there was one univariate outlier (case number 4) which was excluded from further analysis. As the $\mathrm{PhD}$ educational group had only one participant, case number 34 was also excluded. There were no participants with less than high school level of education. In each other educational group there were more than two cases (high school: 18; college: 4; bachelor: 12; master: 4). There were no multivariate outliers in the remaining of the data, as assessed by Mahalanobis distance. There were no multicollinearity $(\mathrm{r}=0.343, \mathrm{p}=0.035)$; and there was a homogeneity of variance-covariance matrices, as assessed by the Box's test $(\mathrm{p}=0.383)$. Descriptive statistics are presented in Table 8 .

The highest mean score for both qualitative and quantitative dimensions of the business success was recorded in the group of female entrepreneurs who had college degrees. The qualitative dimension of the business success is the least significant for female entrepreneurs with bachelor degrees, while the quantitative dimension of the business success is valued the least by female entrepreneurs whose last level of completed education is a high school. As it was the case with the age variable, there was no statistically significant difference between the educational level groups on the combined dependent variables (Table 7). 
Table 8 Educational Levels - Descriptive Statistics

\begin{tabular}{lrrrrr}
\hline & & & \multicolumn{2}{c}{$95 \%$ Confidence Interval } \\
\cline { 5 - 6 } Dependent Variable & Educational & Mean & Std. & Lower & \multicolumn{2}{c}{$\begin{array}{c}\text { Upper } \\
\text { Error }\end{array}$} & Bound & Bound \\
\hline Component 1- Qualitative & high school & 4.417 & .115 & 4.183 & 4.651 \\
& college & 5.000 & .244 & 4.504 & 5.496 \\
& bachelor & 4.354 & .141 & 4.068 & 4.641 \\
& master & 4.562 & .244 & 4.066 & 5.059 \\
\hline Component 2- Quantitative & high school & 3.958 & .163 & 3.628 & 4.289 \\
& college & 4.375 & .345 & 3.674 & 5.076 \\
& bachelor & 3.979 & .199 & 3.574 & 4.384 \\
& master & 4.187 & .345 & 3.486 & 4.889 \\
\hline
\end{tabular}

For the analysis of different educational field groups, no univariate outliers in the educational field data were found. Nevertheless, cases number 12 and 38 were excluded due to inadequate number of participants in the appropriate groups: Humanities and Arts (1 participant); Engineering, manufacturing and construction (1 participant). Number of cases in the remained categories were adequate (Services: 8; General programmes: 5; Education: 8; Social sciences, business and law: 9; Agriculture and veterinary: 2; Science: 3; Health and welfare: 3). There were no multicollinearity $(\mathrm{r}=0.635, \mathrm{p}<0.0005)$, nor multivariate outliers. Finally, there was a homogeneity of variance-covariance matrices, as assessed by the Box's test $(\mathrm{p}=0.052)$. Table 9 shows descriptive statistics for educational fields.

Table 9 Educational Fields - Descriptive Statistics

\begin{tabular}{|c|c|c|c|c|c|}
\hline \multirow[b]{2}{*}{ Dependent Variable } & \multirow[b]{2}{*}{ Educational field } & \multirow[b]{2}{*}{ Mean } & \multirow[b]{2}{*}{$\begin{array}{l}\text { Std. } \\
\text { Error }\end{array}$} & \multicolumn{2}{|c|}{$95 \%$ Confidence Interval } \\
\hline & & & & $\begin{array}{l}\text { Lower } \\
\text { Bound }\end{array}$ & $\begin{array}{l}\text { Upper } \\
\text { Bound }\end{array}$ \\
\hline \multirow{7}{*}{$\begin{array}{l}\text { Component } 1- \\
\text { Qualitative }\end{array}$} & Services & 4.531 & .255 & 4.012 & 5.051 \\
\hline & General programmes & 4.500 & .322 & 3.843 & 5.157 \\
\hline & Education & 4.531 & .255 & 4.012 & 5.051 \\
\hline & $\begin{array}{r}\text { Social sciences, business and } \\
\text { law }\end{array}$ & 4.343 & .240 & 3.853 & 4.832 \\
\hline & Agriculture and veterinary & 3.875 & .509 & 2.836 & 4.914 \\
\hline & Science & 4.917 & .416 & 4.068 & 5.765 \\
\hline & Health and welfare & 3.333 & .416 & 2.485 & 4.182 \\
\hline \multirow{7}{*}{$\begin{array}{l}\text { Component } 2- \\
\text { Quantitative }\end{array}$} & Services & 4.219 & .259 & 3.690 & 4.748 \\
\hline & General programmes & 3.850 & .328 & 3.181 & 4.519 \\
\hline & Education & 4.156 & .259 & 3.627 & 4.685 \\
\hline & $\begin{array}{r}\text { Social sciences, business and } \\
\text { law }\end{array}$ & 3.833 & .245 & 3.334 & 4.332 \\
\hline & Agriculture and veterinary & 3.375 & .519 & 2.317 & 4.433 \\
\hline & Science & 4.500 & .424 & 3.636 & 5.364 \\
\hline & Health and welfare & 2.583 & .424 & 1.719 & 3.447 \\
\hline
\end{tabular}


Both dimensions of the business success are the most important for female entrepreneurs whose education is in the field of Science. The lowest scores on both dimensions are registered among female entrepreneurs educated in the field of Health and welfare. Once again, there was no statistically significant difference between the educational field groups on the combined dependent variables (Table 7). The lack of the statistical importance of the obtained results precludes the acceptance of the second hypothesis.

\section{Discussion}

It is evident that female entrepreneurs perceive the business success through it's both dimensions - the qualitative and the quantitative one. Nonfinancial manifestations of the business success, such as building relationships and achieving satisfaction of the stakeholders and establishing the work-family balance are perceived as the qualitative dimension of the business success. On the other hand, there are the financial and other quantitative aspects of the business success - profit, employment growth, personal wealth. It is interesting that personal goals of female entrepreneurs are strongly related to the quantitative dimension of the business success. Thus, it may be considered that personal goals of female entrepreneurs are mostly based on the achievement of the quantitative business objectives. This finding may not be in line with those suggesting that female entrepreneurs are predominantly interested in the qualitative dimension of the business success (Carter and Bennet, 2006; Clif, 1998; Verheul and Thurik, 2001), and that they are particularly concerned with the relational perspective of the business (Bird and Brush, 2002; Buttner, 2001; Jome et al., 2006). Linking the personal goals to the achievement of the quantitative measures of the success may suggest that female entrepreneurs in the Republic of Serbia see themselves responsible for providing for their family, thus realizing their personal goals. This may be in line with the findings presented by Manolova et al. (2007) suggesting that female entrepreneurs in transition economies link the quantitative growth of their businesses with the economic benefits for their families. According to the age structure of the sample (the dominance of the age group 26-45), it can be assumed that the most of the female entrepreneurs from the sample have a family to take care for. That may be the reason why their personal goals are strongly related to the quantitative dimension of the business success.

Although there was some evidence of differences between female entrepreneurs of different age an educational background regarding the importance of qualitative and quantitative dimensions of the business success, the second hypothesis was not supported. The importance of both qualitative and quantitative dimensions decreases with the age of the respondents. Younger entrepreneurs may have more enthusiasm and ambition (Storey, 2010), which 
may lead to the fact that they appreciate more both of the dimensions of the business success. For all ages and educational groups of female entrepreneurs there was prevalence of the qualitative dimension of the business success, as was shown by the descriptive statistics. Moreover, all aspects of business success that are related to the qualitative dimension of the business success have higher mean scores compared to the mean scores of the variables that are loaded in the quantitative dimension of the business success, in each of the analyzed educational groups (for all levels and for all fields of education). This confirms the opinion that the female entrepreneurs' perception of the business success and related business goals is a complex phenomenon with the dominance of the qualitative, less objective measures such as relationships, satisfaction, workfamily balance (Coleman and Robb, 2009; Jome et al., 2006; Kamberidou, 2013). However, when it comes to the importance attached to the qualitative and quantitative dimensions of the business success, results do not show that there were significant differences between female entrepreneurs of different age $\left(\mathrm{F}(4.70)=1.310 ; \mathrm{p}=0.275 ;\right.$ Wilks' $\Lambda=0.866 ;$ partial $\left.\eta^{2}=0.070\right)$, different educational level $\left(\mathrm{F}(6.66)=0.952 ; \mathrm{p}=0.465 ;\right.$ Wilks' $\Lambda=0.847$; partial $\left.\eta^{2}=0.080\right)$, or different field of education $(\mathrm{F}(12.60)=1.274 ; \mathrm{p}=0.257$; Wilks' $\Lambda=0.635$; partial $\eta^{2}=0.203$ ).

\section{Conclusion}

Entrepreneurial motivation to start their own business is a complex phenomenon made out of qualitative and quantitative factors. The complex structure of the motivation determines the business success aspects that an entrepreneur will favour later on during managing its own business. Female and male entrepreneurs differ regarding their dominant motives for starting the entrepreneurial activity, and this produces differences when it comes to the business goals that they define as the most important ones. In other words, female and male entrepreneurs value different aspects of the business success, with female entrepreneurs favouring the qualitative aspects such as: independence, family-work balance, stakeholders' satisfaction and alike, opposite to the more quantitative aspects such as: profit and growth. However, there are some arguments in favour of the conclusion that referring to the business success preferences not all of the female entrepreneurs are the same.

Different aspects of the business success that were examined are either qualitative or quantitative by their nature as seen by the female entrepreneurs in the Republic of Serbia. In that respect, the first hypothesis was confirmed. The success for female entrepreneurs in the Republic of Serbia, in addition to achieving business growth, implies achieving a balance between the business and family obligations, as well as building and maintaining relationships with customers, employees and other stakeholders. Bearing in mind that the business 
success is perceived as a multidimensional phenomenon, it seems justified to expand the range of business success criteria so as to incorporate the qualitative aspect of the phenomenon. Such an approach would be a good basis for a comprehensive assessment of the female entrepreneurs' performance. In the attempt to examine the level of homogeneity of the female entrepreneurs on this issue, the results of the conducted study suggest that there is some evidence of differences between different age and educational groups of female entrepreneurs. Moreover, the qualitative dimension of the business success has a higher mean score compared to the quantitative dimension in all ages and educational groups of female entrepreneurs. Unfortunately, regarding these differences no statistical importance was found. Bearing in mind methodological drawbacks of the study - refereeing to the small sample size, certain preliminary conclusions regarding the effects of the age and educational background on the evaluation of the business success can be stated but accepted with caution. Also, the unbalanced design of the study (in the MANOVA part) can affect the integrity of the analysis. As there was no statistical importance in the obtained results, it can be said that the importance of qualitative and quantitative aspect of the business success was the same across the groups of female entrepreneurs of different age and educational background. Therefore, no clear evidence to support the second research hypothesis was found. However, this conclusion should be checked on a larger sample. The obtained results may suggest the need to include other aspects of entrepreneurs' individual characteristics in order to investigate whether they impact the importance of the qualitative and quantitative dimensions of the business success for female entrepreneurs.

\section{References}

Alsos, A., Isaksen, E. and E. Junggren (2006) "New Venture Financing and Subsequent Business Growth in Men- and Women-Led Business", Entrepreneurship Theory and Practice, 30 (5): 667-686.

Babović, M. (2012) Polazna studija o preduzetništvu žena u Srbiji, Beograd: Program Ujedinjenih nacija za razvoj.

Bird, B. and C. Brush (2002) "A Gendered Perspective on Organizational Creation", Entrepreneurship Theory and Practice, 26(3): 41-65.

Bird, S. and S. Sapp (2004) "Understanding the Gender Gap in Small Business Success: Urban and Rural Comparisons", Gender and Society, 18(1): 5-28.

Bowen, D. and R. Hisrich (1986) "The Female Entrepreneur: A Career Development Perspective", The Academy of Management Review, 11(2): 393-407.

Budig, M. (2006) "Intersections on the Road to Self-Employment: Gender, Family and Occupational Class”, Social Forces, 84(4): 2223-2239.

Buttner, H. (2001) “Examing Female Entrepreneurs' Management Style: An Application of Relational Frame", Journal of Business Ethics, 29(3): 253-269. 
Buttner, H. and D. Moore (1997) "Women's Organizational Exodus to Entrepreneurship: Self-Reported Motivations and Correlates with Success", Journal of Small Business Management, 35(1): 34-46.

Carter, N., Brush, C., Greene, P., Gatewood, E. and M. Hart (2003), "Women entrepreneurs who break through to equity financing: the influence of human, social and financial capital", Venture Capital, 5(1): 1-28.

Carter, S. and D. Bennett (2006) "Gender and Entrepreneurship", in Carter, S. and D. Jones-Evans (eds.), Enterprise and Small Business - Principles, Practice and Policies, Harlow: Prentice Hall.

Chaganti, R. and S. Parasuraman (1996) "A Study of Impacts of Gender on Business Performance and Management Patterns in Small Business", Entrepreneurship: Theory \& Practice, 21(2): 73-75.

Cliff, J. (1998) "Does one size fit all? Exploring the relationship between attitudes towards growth, gender, and business size", Journal of Business Venturing, 13(6): 523-542.

Coleman, S. and A. Robb (2009) "A comparison of new firm financing by gender: evidence from the Kauffman Firm Survey data", Small Business Economics, 33(4): 397-411.

Gordon, J. and K. Whelan (1998) "Successful professional women in midlife: How organizations can more effectively understand and respond to the challenges", Academy of Management Executive, 12 (1): 8-24.

Jome, L., Donahue, M. and L. Siegel (2006) "Working in the Uncharted Technology Frontier: Characteristics of Women Web Entrepreneurs", Journal of Business and Psychology, 21(1): 127-147.

Kamberidou, I. (2013) "Women entrepreneurs: ' we cannot have change unless we have men in the room', Journal of Innovation and Entrepreneurship, 2(6): 1-17.

Klapper, L. and S. Parker (2010), "Gender and the business Environment for New Firm Creation", World Bank Research Observer, 26(2): 237-257.

Knorr, H., Garzon, D. and D. Martinez (2011) "Motivations and differences upon reconciling professional and personal life: an empirical study of businesswomen and businessmen in Valencian Community", International Entrepreneurship Management Journal, 7(3): 391-412.

Manolova, T., Carter, N., Manev, I. and B. Gyoshev (2007) “The Differential Effect of Men and Women Entrepreneur' Human Capital and Networking on Growth Expectancies in Bulgaria", Entrepreneurship Theory and Practice, 31(3): 407-426.

Morris, M., Miyasaki, N., Watters, C. and S. Coombes (2006) "The Dilemma of Growth: Understanding Venture Size Choices of Women Entrepreneurs", Journal of Small Business Management, 44(2): 221-244.

National Assembly of the Republic of Serbia (2011). Law on Companies. Official Gazette of the Republic of Serbia, Nos. 36/2011 and 99/2011.

Orser, B. and S. Hogarth-Scott (2002) "Opting for Growth: Gender Dimensions of Choosing Enterprise Development", Canadian Journal of Administrative Science, 19(3): 284-300. 
Robichaud, Y., Zinger, T. and R. LeBrasseur (2007) "Gender differences within early stage and established small enterprises: An exploratory study", International Entrepreneurship and Management Journal, 3(3): 323-343.

Rosa, P., Hamilton, D., Carter, S. and H. Burns (1994) "The Impact of Gender on Small Business Management: Preliminary Findings of a British Study" International Small Business Journal, 12(3): 25-32.

Storey, D. J. (2010) Understanding the Small Business Sector, Hampshire: Cengage Learning EMEA.

Stošić, D. (2015) Growth and Development of Small and Medium Sized Enterprises Owned by Female Entrepreneurs, Doctoral Dissertation, Niš: Faculty of Economics University of Niš (Original: Стошић, Д. (2015) Pacm u развој малих и средњих предузећа у власништву предузетнииа, Докторска дисертација, Ниш: Економски факултет.)

Stošić, D. (forthcoming) "Aspects of the Business Success Important to Female Entrepreneurs in Urban Areas of the Republic of Serbia - A Pilot Study“, Economic Annals.

Tan, J. (2008) "Breaking the "Bamboo Curtain" and the "Glass Ceiling": The Experience of Women Entrepreneurs in High-Tech Industries in an Emerging Market", Journal of Business Ethics, 80(3): 547-664.

UNESCO Institute for Statistics (2012) "International Standard Classification of Education - ISCED 2011", Montreal: UNESCO.

Verheul, I. and R. Thurik (2001) "Start-Up Capital: '’Does Gender Matter?", Small Business Economics, 16 (4): 329-345.

Vossenberg, S. (2013) "Women Entrepreneurship Promotion in Developing Countries: What explains the gender gap in entrepreneurship and how to close it?" Maastricht School of Management: Working Paper No. 2013/08: 1-29.

Watson, J. (2002) "Comparing the Performance of Male and Female Controlled Businesses: Relating Outputs with Inputs", Entrepreneurship Theory \& Practice, 26(3): 91-100.

Xavier, S. R., Ahmad, S. Z., Nor, M. L. and M. Yusof (2012) "Women Entrepreneurs: Making a Change from Employment to Small and Medium Business Ownership", Procedia Economics and Finance, 4: 321-334. 


\section{RAZLIKE U ZNAČAJU POJEDINIH ASPEKATA POSLOVNOG USPEHA U ZAVISNOSTI OD STAROSTI I OBRAZOVANJA PREDUZETNICA}

Apstrakt: Cilj rada jeste ispitivanje značaja koji različiti aspekti poslovnog uspeha imaju za preduzetnice u Republici Srbiji, u zavisnosti od njihove starosti i obrazovanja. Empirijsko istraživanje je sprovedeno na uzorku koji je činilo 40 preduzetnica iz nekoliko urbanih područja na teritoriji Republike Srbije. Dobijeni podaci su analizirani primenom Analize glavnih komponenti (PCA) i jednofaktorske Multivarijacione analize varijansi (MANOVA). Rezultati istraživanja ukazuju na to da se posmatrani aspekti poslovnog uspeha u osnovi mogu grupisati oko dve ključne dimenzije poslovnog uspeha oko kvalitativne i kvantitativne dimenzije. Iako je utvrđeno da postoje određene razlike u značaju ovih dimenzija poslovnog uspeha za preduzetnice različitih godina i obrazovanja, ove razlike nisu statistički značajne. Ipak, prikazano istraživanje se može shvatiti kao polazna studija, te se dalja istraživanja, koja bi eventualno podrazumevala realizaciju većeg uzorka, mogu sprovesti polazeći od definisanog konceptualno-metodološkog okvira.

Ključne reči: preduzetništvo žena, poslovni uspeh, obrazovanje, godine starosti 